Department of Pediatrics (Prof. T. Nakamura), Kyoto Prefectural College of Medicine, Kyoto, Japan

\title{
Brain Ultrastructure of the Newborn Rat in Dehydration
}

\author{
Ryuzo Mizuta (水田隆三)
}

Received April 23, 1968

There are numerous and detailed histologic studies on the cerebral edema, but as LUSE (1961) pointed out, little attention has been directed to the morphological changes in cerebral dehydration. Particularly, the ultrastructural changes of the central nervous system in dehydration during the newborn period has not yet been described. Moreover, the clinical cases of dehydration in the newborn have been studied by few authors. Recently dehydration in the newborn has attracted our attention in relation to posticteric encephalopathy.

An increased permeability in the blood brain barrier is believed to be an essential aetiological factor in the occurrence of kernicterus together with hyperbililubinaemia. From the morphological standpoint, it has became a matter of common knowledge that the blood brain barrier consists of the capillary endothelium, capillary basement membrane and pericapillary glial processes. In spite of numerous investigations, however, the morphological detail of the barrier is still obscure. As for the factors influencing the permeability in the barrier, anoxia, inflammation, edema, radiation and brain injury have been counted and many investigators have attempted to examine the brain ultrastructure under these pathological or experimental conditions to confirm an increase of the permeability in the barrier in such injured brains.

The purpose of the present study is to examine the ultrastructural changes in the cerebral cortex occurring in the experimentally induced dehydration in newborn rats with special reference to the effect of this condition on the nerve cells and capillaries.

\section{Materials and Methods}

Forty-eight rats of Wister strain were used for this study. Thirty-six rats ranging in age from one to seven days were experimentally treated and others ranging in age from one to 28 days and adult rats were used as control. In the experimental group, newborn rats ranging in age from one to four days were kept without food and water for 24, 48, 72 and $96 \mathrm{hrs}$. In the case of 24 and $48 \mathrm{hr}$ period of deprivation of food and water every rat showed a moderate weight loss but none died. In the case of $72 \mathrm{hr}$ period of deprivation of food and water approximately half of the rats died, and in the $96 \mathrm{hr}$ period 80 per cent. The control animals (aged 1-7 days, 14, 21 and 28 days and adult rats) were used for the study on the ultrastructural changes at various stages of development.

The skull was removed carefully to avoid an injury to the blood vessels and 
small pieces of tissue, approximately $2-3 \mathrm{~mm}$ in thickness, were cut from the parietal region of the cerebral cortex to be rapidly immersed in a $1 \%$ cold solution of Osmium tetroxide adjusted at $\mathrm{pH} 7.4$ with a veronal-acetate buffer. In the fixative, these pieces were cut so as to be less than $1 \mathrm{~mm}$ thick in any direction, and fixation was continued for one hour at $3^{\circ} \mathrm{C}$. Following the fixation, the blocks were washed briefly in a cold veronal-acetate buffer, stained with a $50 \%$ uranyl acetate solution for one hour and dehydrated in an increasing concentration of ethanol $(70 \%, 90 \%$ and $95 \%$ for 10 min respectively and three changes of absolute ethanol and propylen oxide for $30 \mathrm{~min}$ ). The blocks were then embedded in epoxy-resin and placed in an incubator at $60^{\circ} \mathrm{C}$ for from 24 to $36 \mathrm{hrs}$ to polymerize. The sections were stained with uranyl acetate alone or in combination with lead hydroxide and examined with a Hitachi HU-llA tpye electron microscope.

\section{Observations}

\section{A. Capillaries}

\section{Normal}

The capillary wall consisted of the endothelial cells, the basement membrane and the pericytes. The endothelium formed one continuous sheet without forming fenestration and lay against the basement membrane which completely surrounded the capillary. The endothelial cell contained a large, sometimes irregularly shaped nucleus and had moderate electron density. In the cytoplasm, mitochondria, ribosomes, an endoplasmic reticulum, a Golgi apparatus, centrioles, vesicles, multivesicular bodies and fine filaments were observed. The margins of endothelial cells overlapped one another and the contact between adjacent cells formed the structure called junctional complex. To the outer surface of this endothelium, another kind of cell, the pericyte lay in a random fashion surrounded by the basement membrane completely. The cytoplasmic and nuclear fine structures of the pericyte were similar to those of the endothelial cell (Fig. 1).

As the morphological locus of the blood brain barrier, the capillary endothelium and basement membrane together with the glial processes should be considered. It is known that the barrier is not present until a certain stage of development and it seems very important to investigate the capillary ultrastructure at various stages of development. Donahue and Pappas (1961) described the gradual changes in the structure of the capillary in the central nervous system with increasing age. They reported that the basement membrane, already present before birth, gradually increased in thickness and electron density with age until the adult age was reached, and the endothelial cell relatively thick in the immature rat became attenuated in the adult. The present study demonstrated no such remarkable cytologic differences with increasing age as Donahue and PAPpas had described. In the newborn rat, endothelial cytoplasm contained numerous vesicles and ribosomes and was usually thick. With increasing age the endothelial cells had a tendency to lose their thickness and electron density, and in the adult, the cytoplasm was attenuated and contained fewer vesicles than in the immature rat. But these changes were only slight in degree. The thickness of the basement membrane was variable in rats of different ages. 


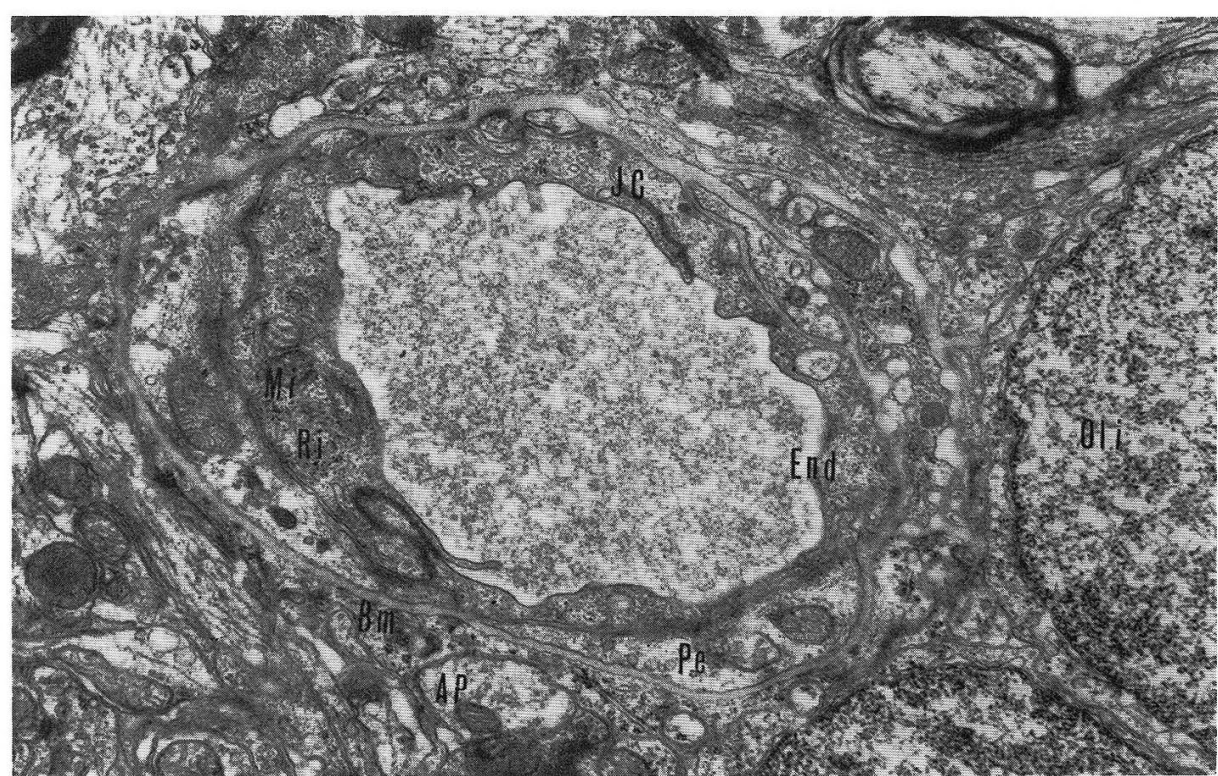

Fig. 1. An entire capillary in the normal cerebral cortex of a 28-day-old rat. The endothelial cell (End) contains a moderate amount of organelles and forms a continuous layer. A continuous basement membrane $(\mathrm{Bm})$ envelops the entire capillary. Pe pericytes, Mi mitochondria, Ri ribosome, $J C$ junctional complex, $O l i$ oligodendroglia, $A P$ astrocytic process. $\times 14,000$

\section{Dehydration}

The experimentally treated rats were classified into three groups according to the degree of brain damage caused by the different periods of dehydration. In the following description, the findings after a $48 \mathrm{hr}$ period of dehydration was presented as changes by mild dehydration, those after a $72 \mathrm{hr}$ period as changes by moderate dehydration and those a $96 \mathrm{hr}$ period as changes by severe dehydration. The severity of the cytologic changes could usually be correlated to the duration of the dehydration, but in some cases this relation did not apply.

\section{a. Mild dehydration}

The endothelial cells appeared somewhat swollen though the capillary outline was smooth and round. The endothelial cytoplasm becamc more electron-dense than the normal partly because of an increase in the number of cytoplasmic organelles; it contained numerous vesicles variable in size. The mitochondria varied considerably in shape. Some of them were slightly dilated and showed a mild fragmentation of their cristae. The channels of the endoplasmic reticulum were expanded slightly. The nuclei showed no remarkable changes, but if remotely compared, chromatin granules increased in number and the nucleoplasm was more electron-dense than the normal.

The pericytes showed the same changes as the endothelial cell. The basement membrane and junctional complex retained their normal structure (Fig. 2). 


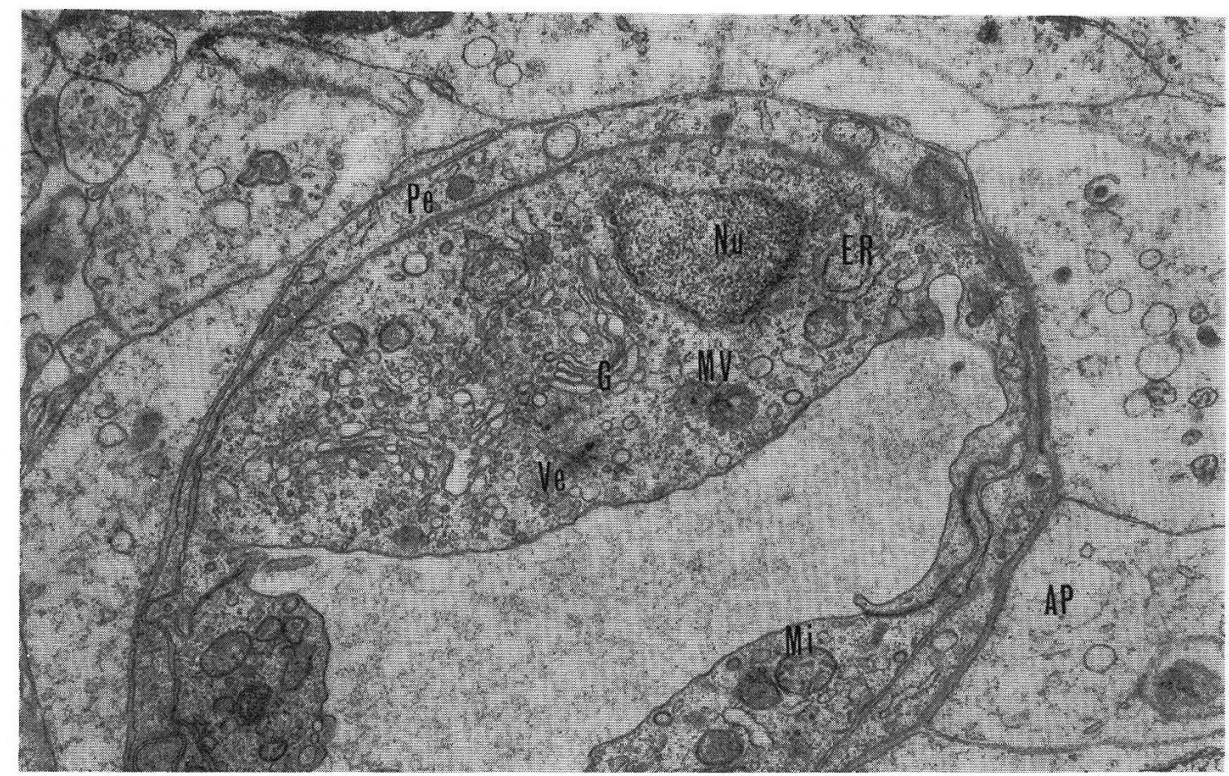

Fig. 2. A capillary in the cerebral cortex of a 3-day-old rat, $48 \mathrm{hr}$ dehydration. There are increased vesicles $(V e)$ in the cytoplasm. The capillary outline is smooth and its surface is surrounded entirely by astrocytic end-feet $(A P)$. Mi mitochondria, $E R$ endoplasmic reticulum, $G$ Golgi complex, $M V$ multivesicular body, $N u$ nucleus, $P e$ pericyte. $\times 20,000$

\section{b. Moderate dehydration}

As the dehydration went on, cytologic changes, such as endothelial swelling, mitochondrial degeneration and vesicle formation became still more conspicuous. There appeared numerous vesicles of variable sizes and expanded channels of the endoplasmic reticulum. The mitochondria became irregular in size and shape with the fragmentation of their cristae, dissolution of the matrix or destruction of the membrane. Some of the endothelial cells swelled and bulged into the capillary lumen so rcmarkably as to compress the blood cells in the lumen. The outline of the capillary lost its smooth roundness and became uneven. The nuclei increased their electron density and became irregular in shape. The nuclear membranes became notched and the outer membrane parted from the inner membrane projecting into the cytoplasm.

A similar increase in vesicles and vacuoles also occurred in the pericyte. The basement membrane became irregular and increased in thickness. A myelin-like structure was recognized in the capillary endothelium of moderately dehydrated cases. The details of this structure will be described in the following section. Glial processes, especially pericapillary end-feet, showed a tendency to decrease in volume, and the destruction of the astrocytic processes was observed frequently (Fig. 3, 4).

\section{c. Severe dehydration}

In severely dehydrated cases, the outline of the capillary became more and more irregular. The endothelial cells were strikingly swollen and bulged into the lumen. As the dehydration went on, their cytoplasm became less dense and this decrease in 

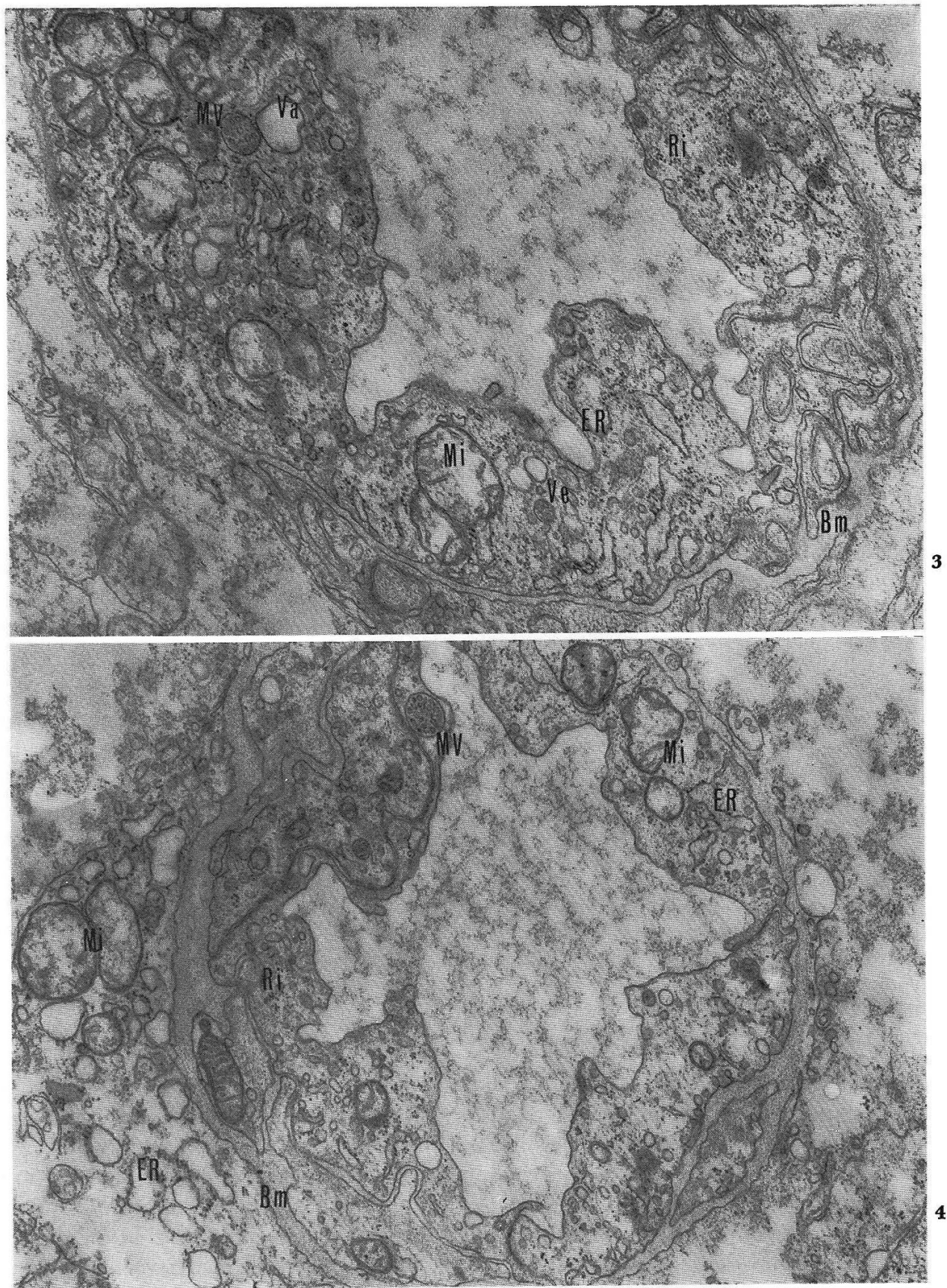

Fig. 3. A capillary in the cerebral cortex of a 5-day-old rat, $72 \mathrm{hr}$ dehydration. The endothelium bulges into the lumen and contains numerous vesicles $(V e)$, vacuoles $(V a)$, distended endoplasmic reticulum $(E R)$, swollen mitochondria $(M i)$ and a multivesicular body $(M V)$. Bm basement membrane, $R i$ ribosome. $\times 20,000$

Fig. 4. A capillary in the cerebral cortex of a 6-day-old rat, $72 \mathrm{hr}$ dehydration. The outline of the capillary is irregular. The basement membrane $(B \mathrm{~m})$ increases in width and normal astrocytic endfeet are not seen. $M i, E R, R i, M V$ : see above. $\times 20,000$ 
electron density was associated with a decrease in mitochondria, endoplasmic reticulum, ribosomes and vesicles. Endothelial swelling continued until the entire capillary lumen was eventually obliterated and the blood cells in the lumen were strongly compressed. Mitochondria decreased in number and most of them swelled up with a fragmentation or disappcarance of their cristae, causing them to look like empty vacuoles. These vacuoles could only be identified as mitochondria by their double limiting membranes. The rough surfaced endoplasmic reticulum decreased in number and its channels were expanded. Free ribosomes also decreased and were frequently found in clusters or rosettes. Pinocytotic vesicles were usually numerous in the dehydrated cases, but there was a tendency to decrease in severcly dehydrated rats. At the junction of the two adjacent endothelial cells a thin fold disappeared entirely and the finger-like extensions into the lumen became relatively few. The junctional complex kept its normal structure even in the severely dehydrated cases but in some cases, the region of the tight junction in which the outer membranes of both adjacent cells fuse into a single membrane became defective suggesting the opening of the tight junction (Fig. 5). The nuclei lost their electron density and the

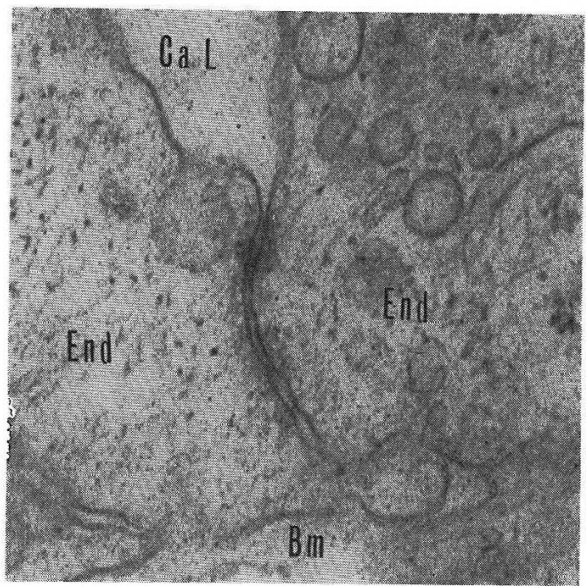

Fig. 5. End endothelial cell, CaL capillary lumen, $B m$ basement membrane. $\times 75,000$ nuclear membranes became notched. In the nucleoplasm chromatin granules formed peripheral granular aggregations and the nucleolus occasionally became obscure.

The basement membrane became irregular and showed considerable variation in thickness. The typical three-layered structure of the basement membrane became indistinct and the outer layer became disorganized after the destruction of the surrounding astrocytic membranes. Pericytes were hardly observed in severely affected cases. Glial processes lost their normal structure, and a marked destruction of their surface membranes was seen (Fig. 6, 7).

\section{d. Myelin figure in the capillary endothelium}

A myelin-like structure in the capillary endothelium was occasionally found in a 5 and 6-day-old rat, both sacrificed after starvation for $72 \mathrm{hrs}$. Its shape was ovoid and its lamellar structure was very clear. The electron density of the lamellae was very high. In the center of the concentrically arranged lamellae, vacuoles and ribosomes were observed. In contrast to these lamellae, gencral mcmbrancs of the cytoplasm were found, under high magnification, to have the double membrane structure with a dense line of $50 \AA$, a pale zone of $100 \AA$ and a dense line of $50 \AA$ (Fig. 8, 9). Though a whorl of membranes, which appeared to be a reduplication of the membrane, was also encountered occasionally in the endothelial cell and pericyte, there was no intimate relation between this and the myelin figure (Fig. 10, 11). 

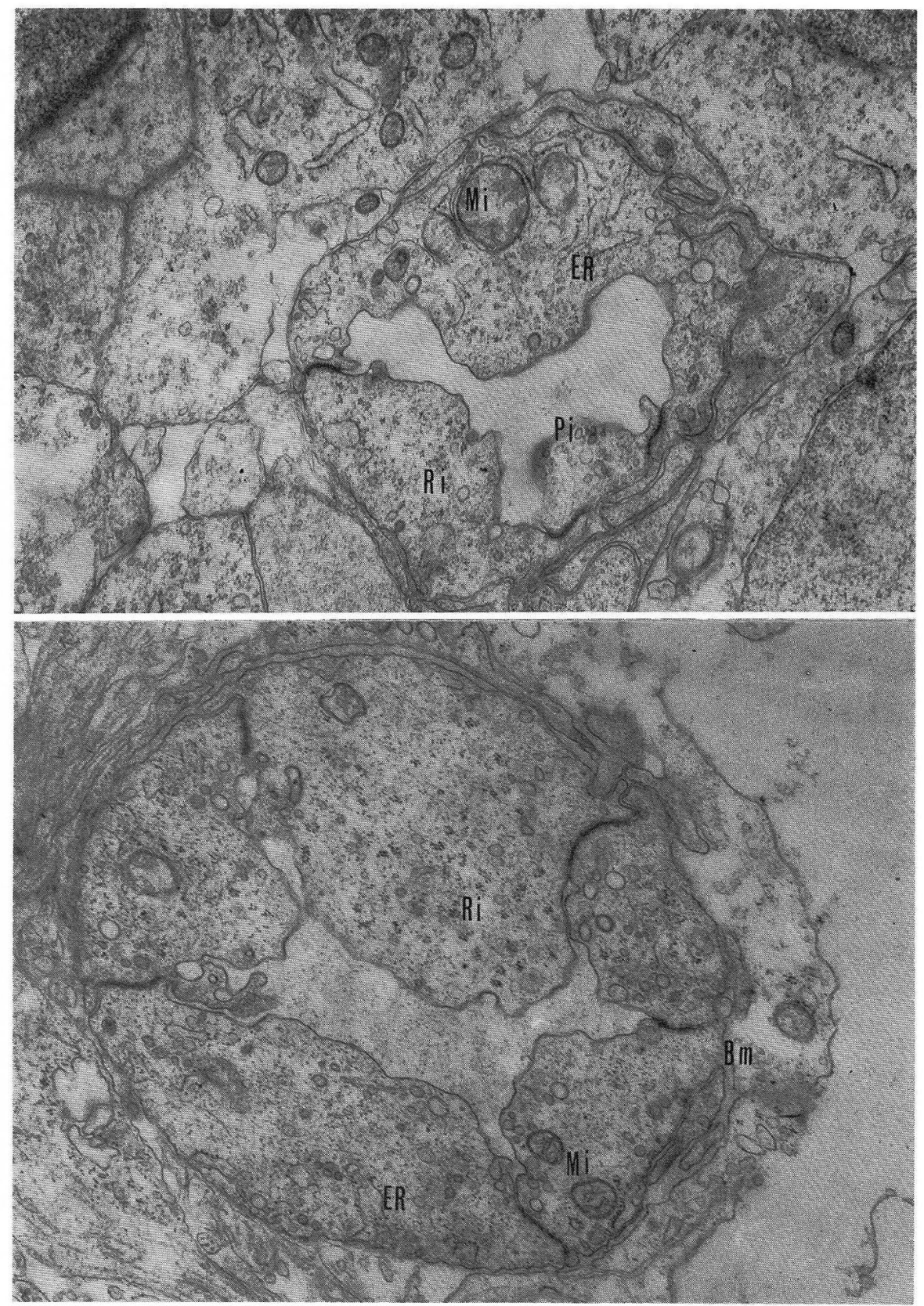

Fig. 6. A capillary in the cerebral cortex of a 7-day-old rat, $96 \mathrm{hr}$ dehydration. The endothelium of decreased density strongly bulges into the lumen. Pinocytotic vesicles $(P i)$ are still abundant and decreased mitochondria $(M i)$ show swelling and fragmentation. $E R$ endoplasmic reticulum, $R i$ ribosomes. $\times 20,000$

Fig. 7. A capillary from the same brain in Figure 7. The endothelial cells are extremely swollen. The basement membrane $(B m)$ is indistinct after the destruction of the surrounding astrocytic end-feet. Ribosomes $(R i)$ are found in rosettes in the rarefied cytoplasm. Mi mitochondria, $E R$ endoplasmic reticulum. $\times 20,000$ 

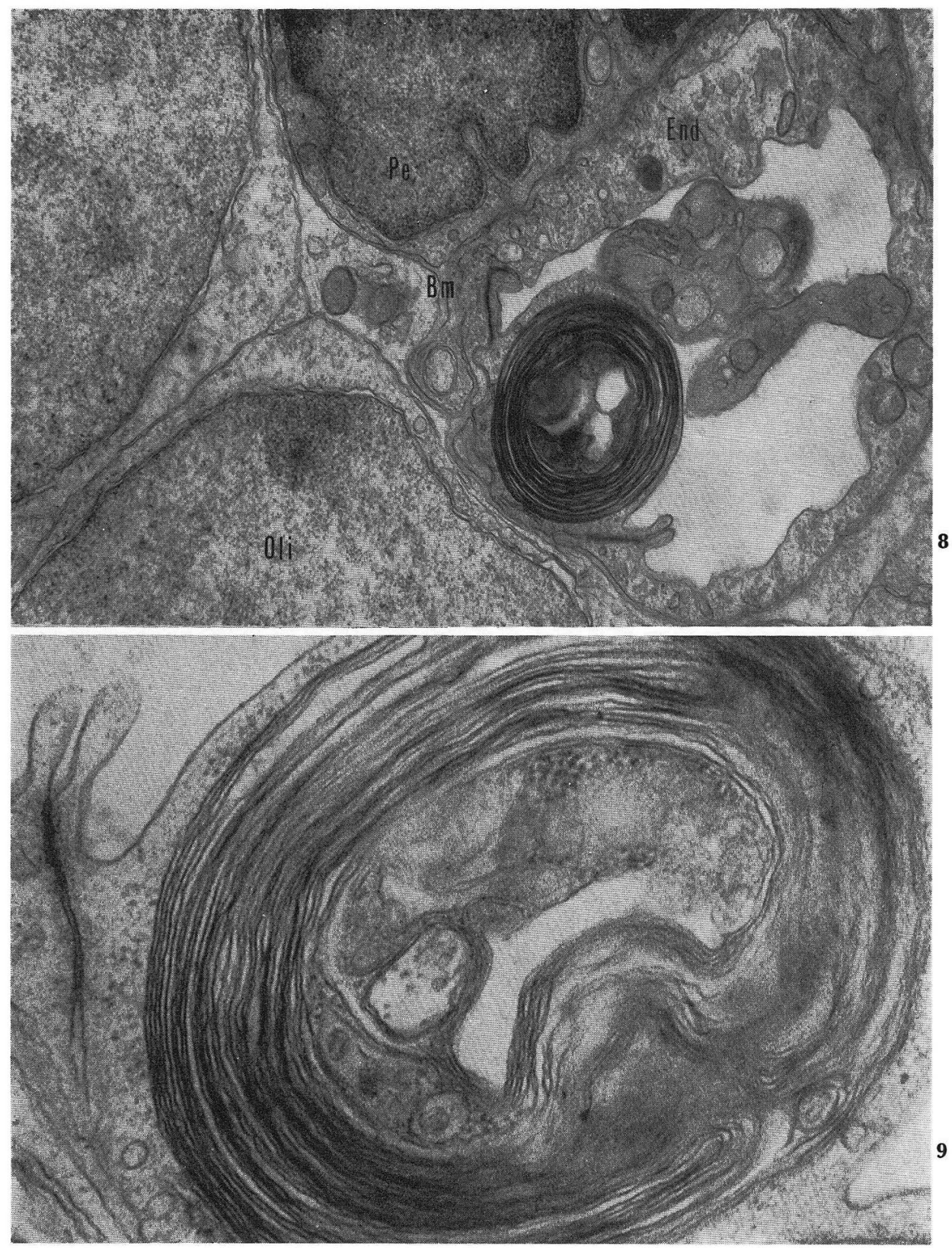

Fig. 8. A capillary in the cerebral cortex of a 5-day-old rat, $72 \mathrm{hr}$ dehydration. The myelin-like body with a clear lamellar structure is seen in the endothelium. End endothelial cell, $P e$ pericyte, $B m$ basement membrane, Oli oligodendroglia. $\times 16,000$

Fig. 9. The myelin-like structure found in the capillary endothelium of a 5-day-old rat. $72 \mathrm{hr}$ dehydration. $\times 56,000$ 


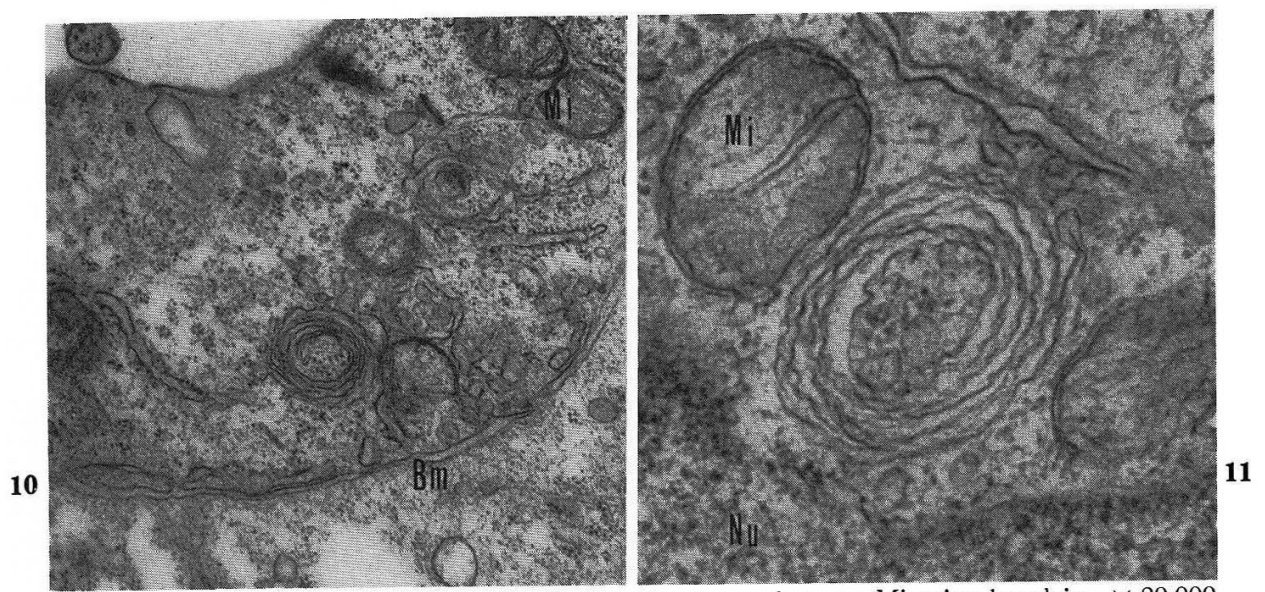

Fig. 10. A part of an endothelial cell. $B m$ basement membrane, $M i$ mitochondria. $\times 20,000$

Fig. 11. A part of an endothelial cell. $N u$ nucleus, $M i$ mitochondria. $\times 60,000$

\section{b. Nerve Cells}

\section{Normal}

Identification of the nerve cell was made by its ribonucleoprotein-rich cytoplasm and fine neural filaments running in bundles through the perikaryon and dendrites. The cells varied considerably in size and shape as well as in the distribution of the cytoplasmic organelles. The nerve cell contained a large irregularly oval nucleus with dispersed chromatin granules. One or two distinct nucleoli appeared as a dense aggregation of fine granules. The double nuclear envelope and its discontinuity at the sites of the nuclear pores were clearly recognized.

In the cytoplasm there were mitochondria, ribosomes, a Golgi apparatus, abundant profiles of a granular endoplasmic reticulum, centrioles, neurofilaments, lysosomes, lipid droplets and microvesicles. The most available criterion for identifying the nerve cell is the presence of neural filaments and Nissl substance which corresponds to an accumulation of the cisterns of the granular endoplasmic reticulum. The neurofilaments were long threads with a width approximating 100 to $200 \AA$ and traversed the cytoplasmic matrix between the cisterns of the endoplasmic reticulum and other organelles. The detailed structure of the Golgi apparatus and mitochondria were much like those of other cells (Fig. 12).

\section{Dehydration}

\section{a. Mild dehydration}

There was no increase in cytoplasmic organelles. Mitochondria showed a tendency to shrink with the increased density of the matrix. The endoplasmic reticulum usually dilated its cisternae, Nissl bodies being well preserved. A vesicular change, though rarely, appeared in the Golgi complex, i. e. an increase in size and number of its vacuolar and vesicular elements. Neurofilaments and ribosomes were usually distributed in the ordinary manner. The nuclei showed no special changes except a 


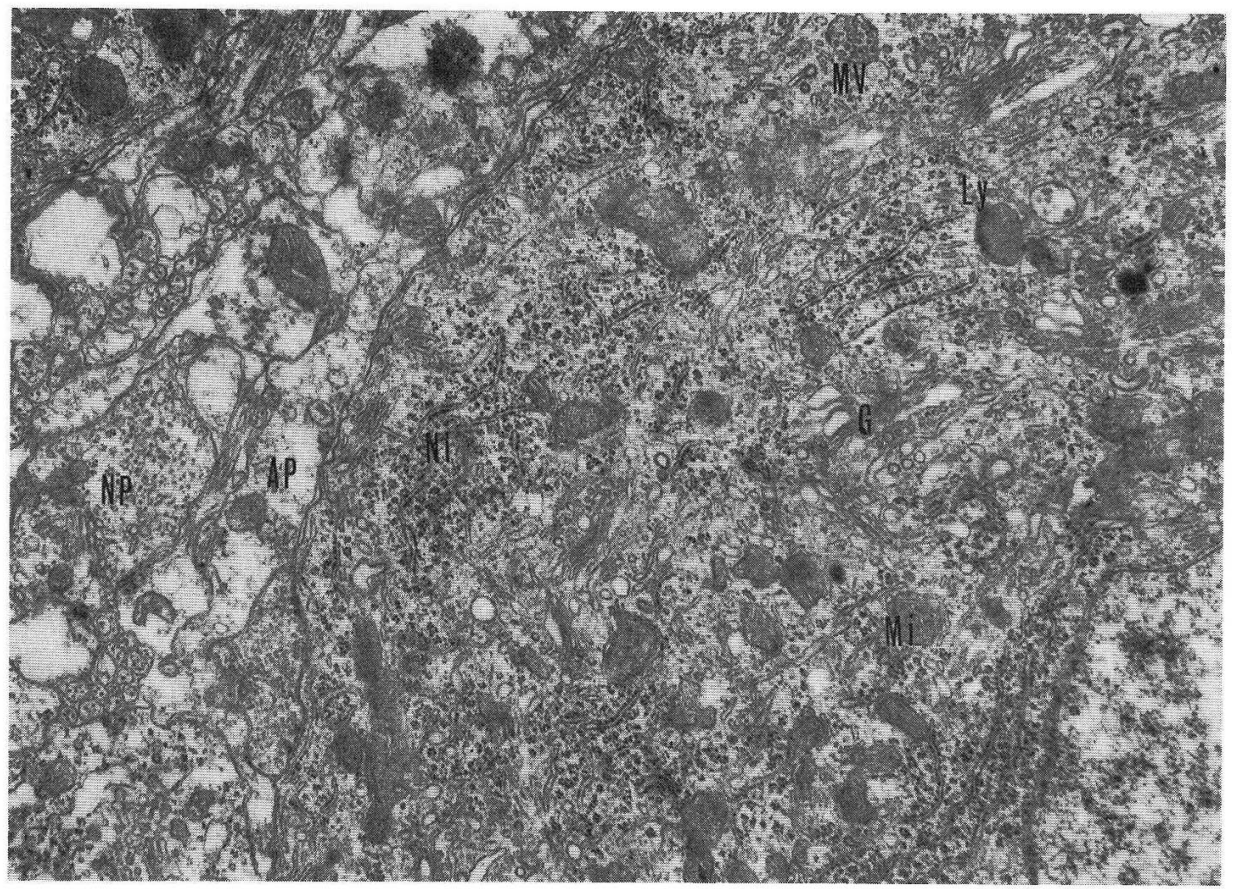

Fig. 12. A nerve cell in the normal cerebral cortex of a 28-day-old rat. The cytoplasm contains mitochondria $(M i)$, Golgi complex $(G)$, lysosome $(L y)$, multivesicular body $(M V)$ and characteristic Nissl bodies $(N i)$. $A P$ astrocytic process, $N P$ neuronal process. $\times 12,500$

mild undulation of the outer nuclear membrane (Fig. 13, 14).

\section{b. Moderate dehydration}

Most of the mitochondria were considerably swollen and became irregular in shape. The swollen mitochondria showed fragmentation or disappearance of the cristae and the electron-lucid appearance of the matrix. The endoplasmic reticulum enlarged its cisternae more and more and frequently exhibited vacuolar dilatation. As the vacuolar alteration of the endoplasmic reticulum became conspicuous, the Nissl bodies seemed more or less disorganized. In some cases, the Nissl bodies were deranged by marked vacuolar alteration and a decrease in ribosomes attached to the endoplasmic reticulum. The Golgi complex lost its original tubular and vesicular structure forming numerous vacuoles. This vacuolar alteration was diffuse and profound and the vacuoles became occasionally very large, occupying the greater part of the cytoplasm. When the Nissl bodies were deranged, a discrimination of the nerve cells from reactive oligodendroglial cells was difficult and often impossible.

The nucleus of the nerve cell usually kept its round or oval outline. Chromatin granules gradually aggregated in clumps and the nucleolus stood out in the rarefied nucleoplasm. The inner and outer nuclear membranes were inclined to separate, and the widely separated outer membrane formed vacuoles.

In the axons and dendrites, vacuolar alteration and mitochondrial degeneration were also observed in the same way (Fig. 15, 16). 

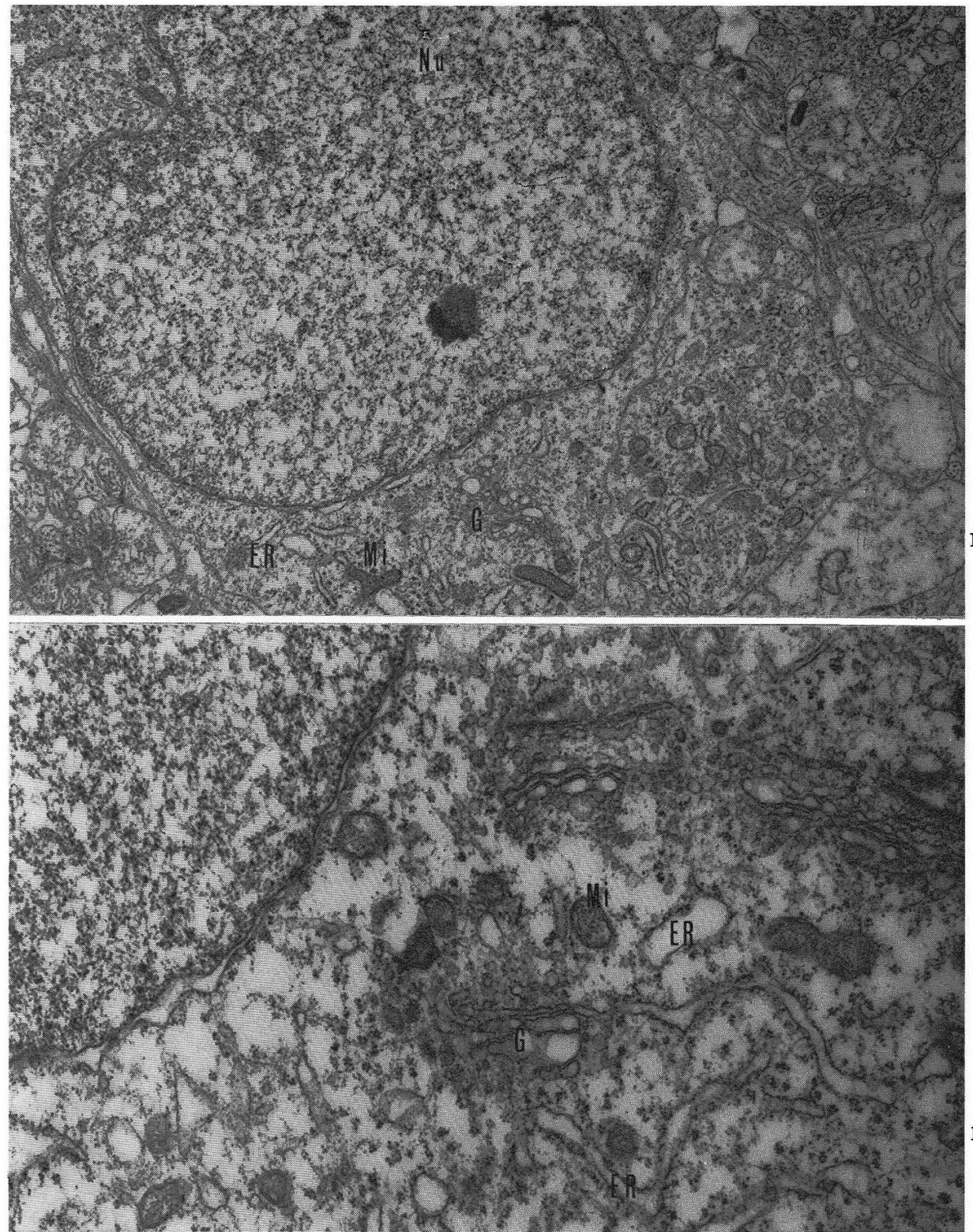

Fig. 13. A nerve cell in the cerebral cortex of a 4-day-old rat in dehydration of 48 hr duration. The cytoplasm and nucleus $(N u)$ keep normal structure as a whole. Mi mitochondria, ER endoplasmic reticulum, $G$ Golgi complex. $\times 10,000$

Fig. 14. A nerve cell in the cerebral cortex of a 3-day-old rat in dehydration of $48 \mathrm{hr}$ duration. Vesicular formation appears in the Golgi complex $(G)$ and mild dilatation of the endoplasmic reticulum $(E R)$ is seen. Mitochondria $(M i)$ gradually shrink with increased density of the matrix. 

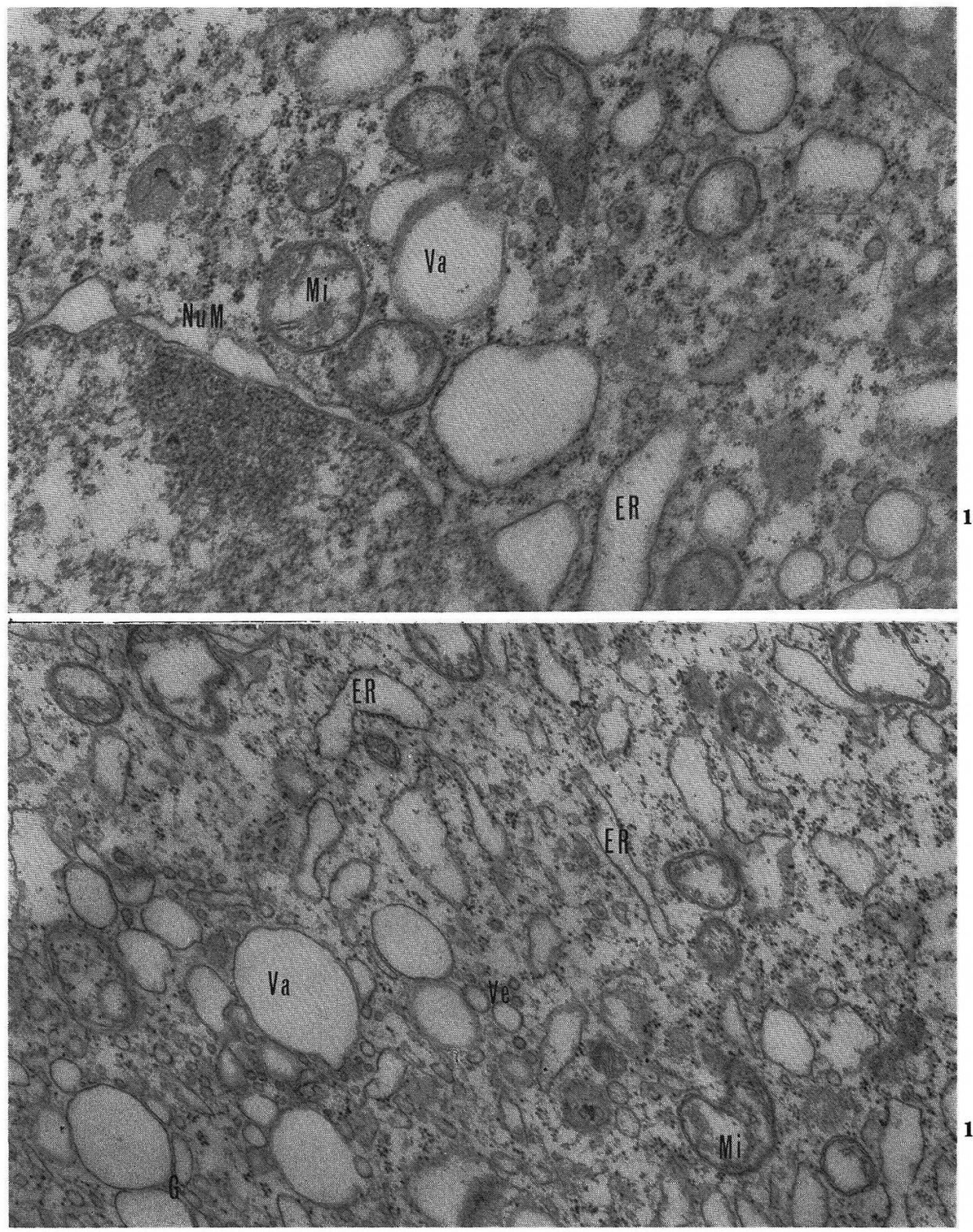

Fig. 15. A nerve cell in the cerebral cortex of a 4-day-old rat, $72 \mathrm{hr}$ dehydration. Note the unduration and separation of the outer nuclear membrane and the vacuolar dilatation of the rough surfaced endoplasmic reticulum $(E R)$. $V a$ vacuole, $M i$ mitochondria, $N u M$ nuclear membrane. $\times 24,000$

Fig. 16. A nerve cell in the cerebral cortex from the same rat in Figure 15. Golgi complex $(G)$ loses its original tubular structure forming numerous vacuoles $(\mathrm{Va})$ and vesicles $(\mathrm{Ve})$. Mitochondria (Mi) show electron-lucid appearance of the matrix. ER endoplasmic reticulum. $\times 25,000$ 


\section{c. Severe dehydration}

The cytoplasm was usually rarefied with a decrease in mitochondria, granular endoplasmic reticulum, ribosomes and vesicles. Mitochondria decreased in number and swollen mitochondria were returning to their original size and shape. Vacuolar changes of the cisternae of the endoplasmic reticulum became still more conspicuous and, in case of an advanced rarefaction of the cytoplasm, disappearance of the orderly arrangement of the endoplasmic reticulum could result in the complete absence of Nissl bodies. Free ribosomes were few and lay at the rarefied cytoplasm in clumps or rosettes. The Golgi complex lost parallel arrangement of its cisternae by this time. The disappearance of the endoplasmic reticulum and mitochondria seemed to be caused by the destruction of the extremely swollen ones. A considerable number of vesicles and vacuoles were still observed in the rarefied cytoplasm.

The nucleus lost its roundish shape and the nucleolus was shrunken or disappeared. Significant rarefaction of the nucleoplasm was observed also and abnormally clumped dense chromatin appeared in the nucleoplasm. Inner and outer nuclear membranes were widely separated or largely interrupted and finally disappeared resulting in free communication between the cytoplasm and nucleoplasm.

Necrotic nerve cells were particularly prominent where the satellite glial cells or neighbouring capillaries had also undergone severe alteration (Fig. 17, 18).

\section{G. Glial Cells}

\section{Normal}

Concerning the identification of the astrocyte and oligodendroglia, there are two different opinions. Luse (1956) and Dempsey (1958) claimed to have found oligodendroglia with pale cytoplasm, and astrocytes with dark cytoplasm. On the contrary, the conclusion of other investigators was that astrocytes had light, wateryappearing cytoplasm and oligodendroglia had dense cytoplasm (FARQUHAR, 1955; Farquhar and Hartman, 1957; Sahultz et al., 1957; Honjin, 1960 ; Schultz, 1964 ; KrUger and MaXwell, 1966).

In agreement with the latter group of authors, astrocytes were identified in the present study as cells with abundant watery cytoplasm containing relatively few mitochondria, a small mass of endoplasmic reticulum, a few small vesicles and ribosomes. The nuclei of astrocytes were usually round and larger and less dense than that of other types of glial cells. The chromatin in the nucleoplasm was usually clumped and nucleoli were conspicuous. Astrocytic processes could be recognized also by their low density with only a few mitochondria.

Oligodendroglial cells could be identified by their small size and moderately dense cytoplasm which contained a moderate number of mitochondria, elements of granular endoplasmic reticulum and a few sparse groups of Golgi apparatus. Their morphological relationship to other cells was also an important criterion in the identification of these cells because they often lie in the satellite position to neurons. The oligodendroglial cell had an oval and occasionally irregular nucleus which contained conspicuous blobs of chromatin, especially concentrated at the nuclear envelope. They were consistently smaller and denser than the nucleus of astrocytes, and nucleoli were not conspicuous. 

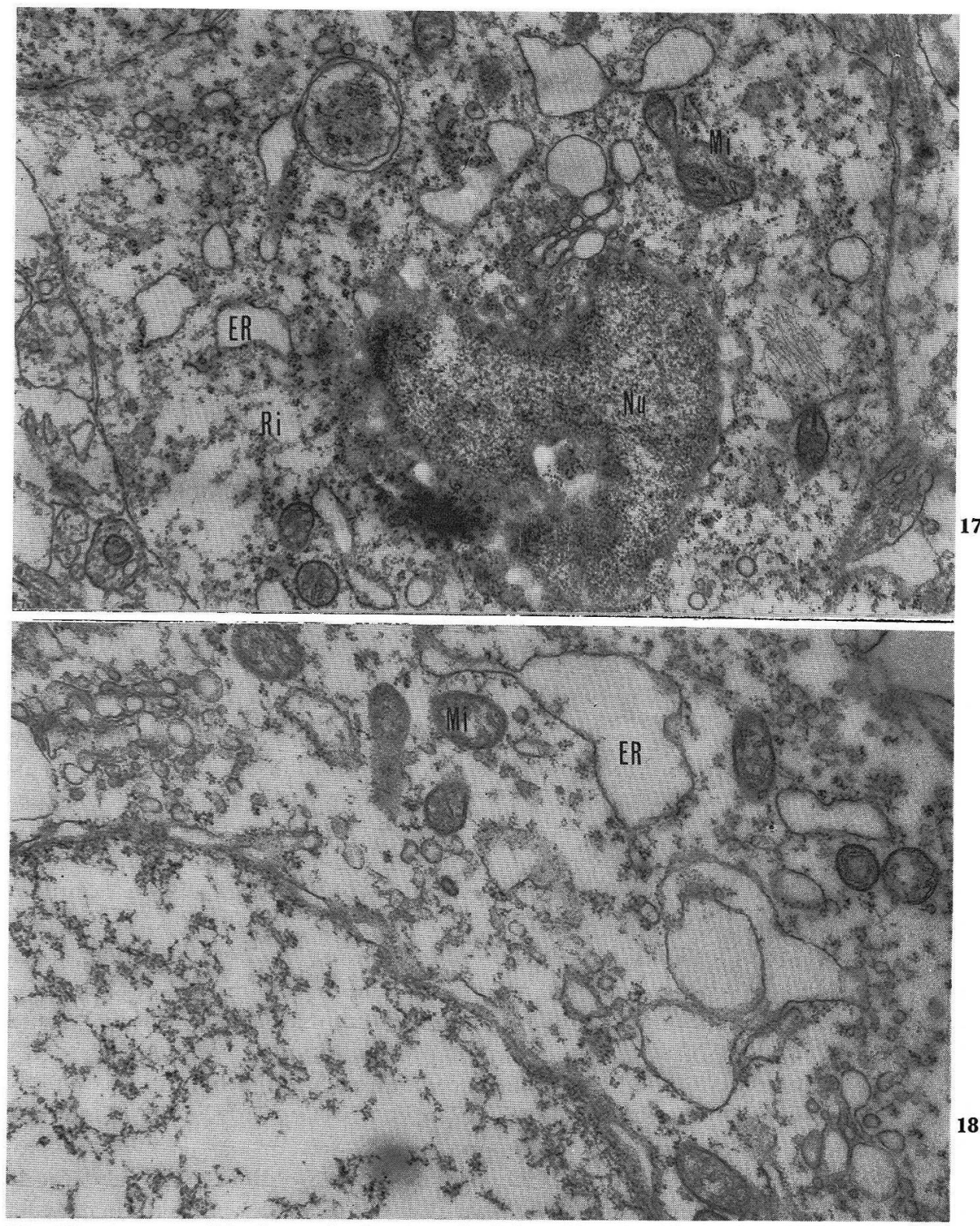

Fig. 17. A nerve cell in the cerebral cortex of a 6-day-old rat in dehydration of 96 hr duration. The nucleus $(N u)$ loses its normal shape and structure. Ribosomes $(R i)$ are found in clusters or rosettes. $M i$ mitochondria, $E R$ endoplasmic reticulum. $\times 16,000$

Fig. 18. A nerve cell in the cerebral cortex of a 8-day-old rat in dehydration of $96 \mathrm{hr}$ duration. Mitochondria $(M i)$ are returning to their normal size and structure. The nucleoplasm is rarefied remarkably. Vacuolar changes of the cisterns of the endoplasmic reticulum $(E R)$ are conspicuous. $\times 20,000$ 


\section{Dehydration}

\section{a. Astrocyte}

Astrocytes retained their normal cytoplasmic density and normal concentration of mitochondria, ribosomes and endoplasmic reticulum in mild dehydration. On rare occasions free ribosomes decreased in number and were dispersed in clusters and rosettes. The nucleus showed its normal density and normal distribution of chromatin.

In moderate dehydration, shrinkage of the cell body and irregularity of cellular and nuclear membrane were observed. The mitochondria became swollen on rare occasions. The granular endoplasmic reticulum dilated its cisternae, but usually not so much as to exhibit vacuolar formation. These cytologic changes, shrinkage of the cell body in particular, were not constant and complete astrocytes were seen frequently in spite of long term dehydration.

In severe dehydration, the cytoplasm was usually rarefied and with an advanced rarefaction of the cytoplasmic matrix, the orderly arrangement of the organelles came to be lost more or less completely. Shrinkage of mitochondria and mild dilatation of the cisternae of the endoplasmic reticulum were seen.

In general, it may be said that astrocytes are resistant to damage by dehydration compared with oligodendroglial cells (Fig. 19).

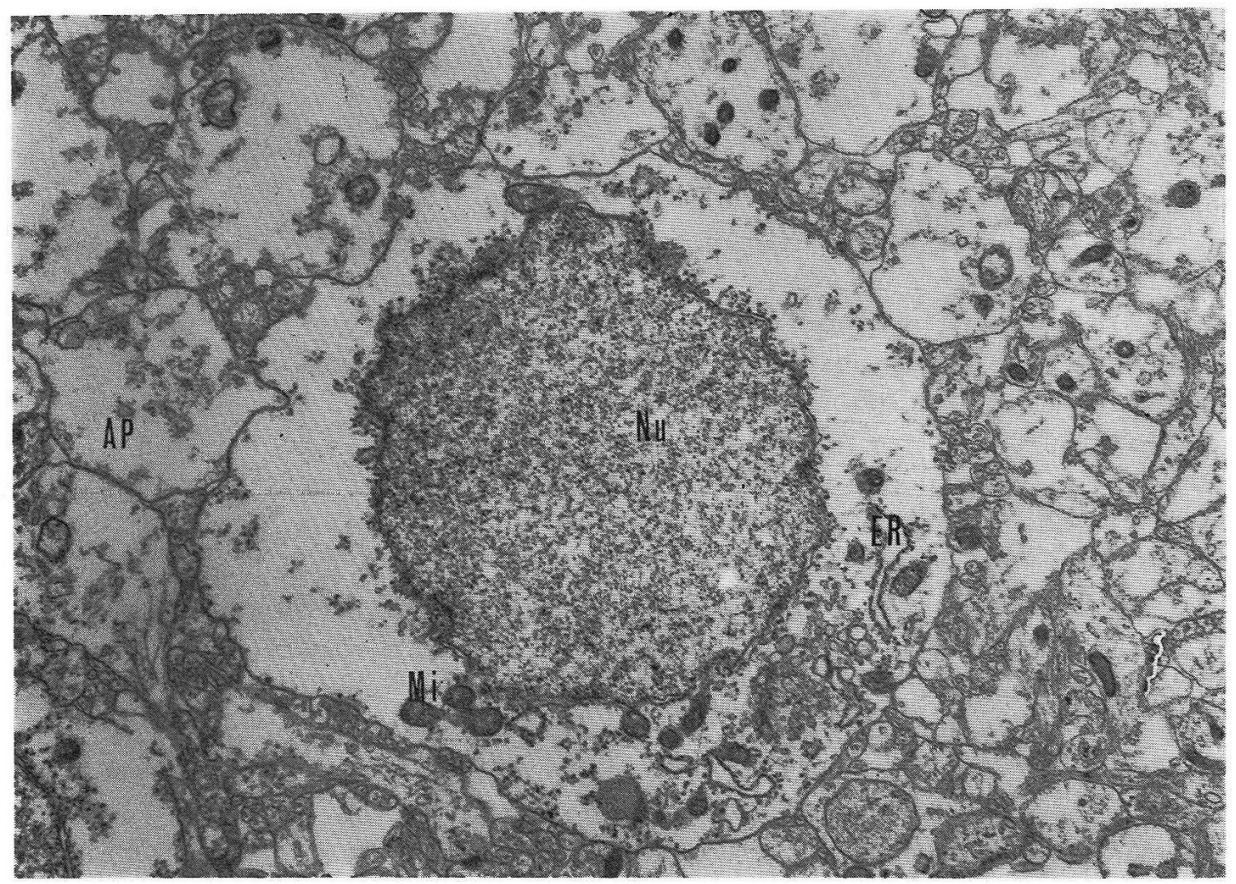

Fig. 19. An astrocyte in the cerebral cortex of a 6-day-old rat, $96 \mathrm{hr}$ dehydration. Shrinkage of the nucleus $(N u)$ and cell body is obvious. $M i$ mitochondria, $E R$ endoplasmic reticulum, $A P$ astrocytic process. $\times 8,000$ 


\section{b. Oligodendroglia}

In mild dehydration, the narrow cytoplasm of the oligodendroglial cells contained a considerable number of mitochondria, elements of the rough-surfaced endoplasmic reticulum, free ribosomes and small vacuoles which seemed to be formed mainly by the dilated Golgi complex. Mitochondria kept their normal size and shape, but swollen mitochondria with fragmental cristae were occasionally seen. The cisternae of the endoplasmic reticulum tended to be dilated, though not so much as to exhibit vacuolar formation. Only occasionally, very large vacuoles occupied the greater part of the cytoplasm and, in this case, cytoplasmic matrix became strikingly dense. The nuclei retained their normal structure as a whole though the nuclear membranes became uneven on rare occasions.

In moderate dehydration, intracytoplasmic organelles were more abundant than in mildly dehydrated cases. Mitochondria were considerably swollen and, moreover, it was frequently found that their cristae became fragmental or disappeared and their matrix became electron-lucid. The nuclei lost their round and oval shape and the nucleoplasm increased its density. The inner and outer nuclear membranes were frequently separated forming large and slender cisterns.

There were numerous vesicles and vacuoles variable in size in severely dehydrated cases. Identification of the cell types in severe dehydration especially between the nerve cell and oligodendroglial cell was very difficult and often impossible. In severely affected cases, extracellular spaces which probably developed by cellular destruction became conspicuous and the cortex became a mass of debris (Fig. 2022).

\section{Discussion}

There are numerous electron microscopical studies concerning cerebral edema, but strangely enough only a few morphological studies are known concerning cerebral dehydration. It has been accepted that in early neonatal stage mammals are resistant to harm from anoxia or dehydration compared with adults. An intimate relation between posticteric encephalopathy and asphyxia was recognized clinically. A decrease in activity of the blood brain barrier in anoxia was confirmed experimentally by WARREN and Sahenker (1960), but the effect of dehydration on the developing and neonatal brain remains to be elucidated. ReID (1943) described the shrinkage of the brain following an intravenous injection of hypertonic dextrose and illustrated only the dense shrunken cortical neurons of dehydration. Subsequently, STERn and ELLiot (1949) studied the cerebral dehydration morphologically but they did not mention the neuronal and glial changes in detail. LusE and HARRIS (1961) demonstrated the cytologic abnormalities in cerebral dehydration and remarked that cytologic changes in dehydration were the reverse of those in the brain edema. They reported that the principal changes in cerebral dehydration occurred in the oligodendroglial cytoplasm and capillary endothelium. The oligodendroglial cytoplasm was reduced so much in volume that only a narrow pale rim remained about the nucleus and its processes were virtually unrecognizable. As to the neuronal changes they reported that neurons had dense contracted cytoplasm and their nuclei showed an increased indentation in their membranes. 

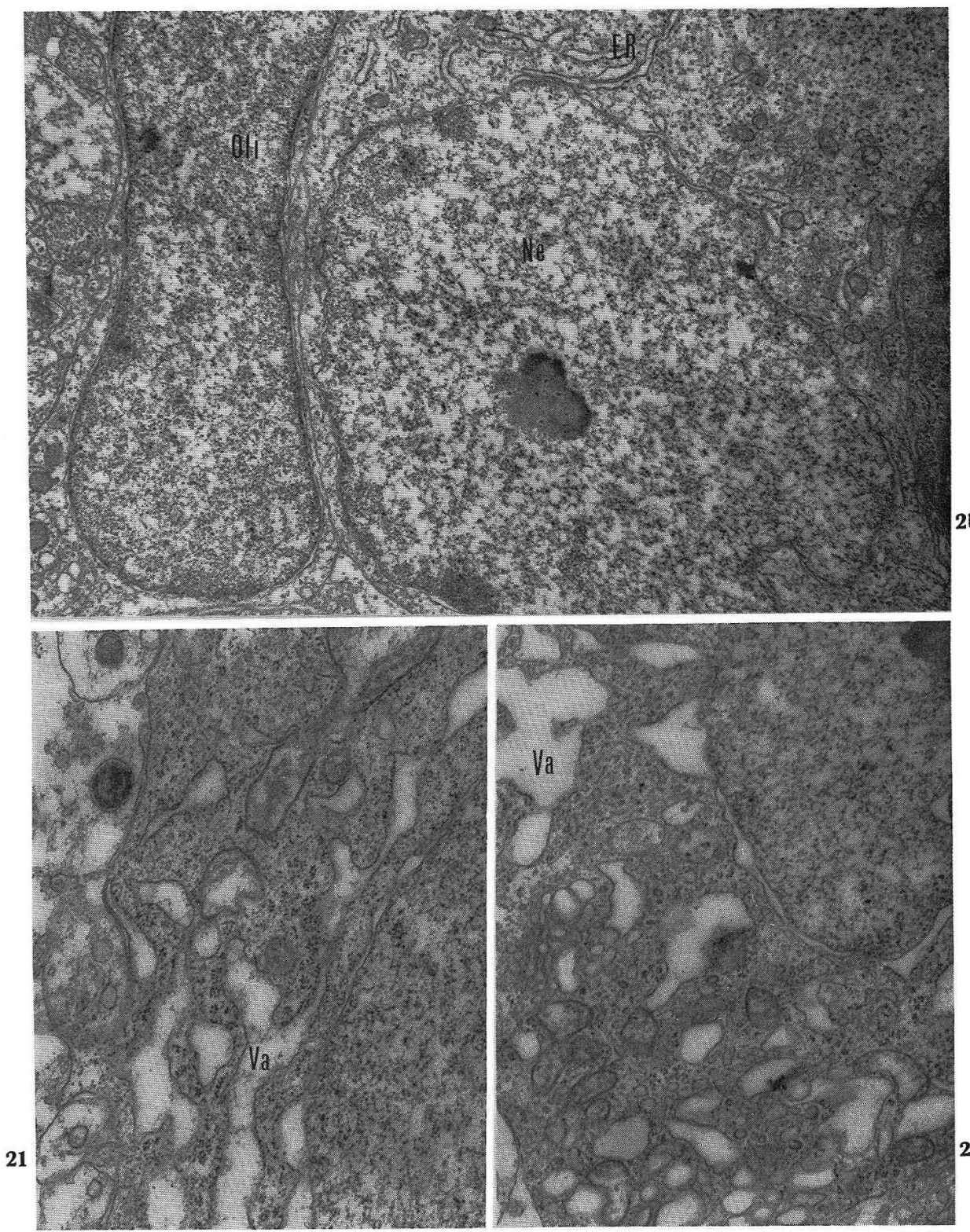

Fig. 20. An area of the cerebral cortex of a 3-day-old rat, $48 \mathrm{hr}$ dehydration. A nerve cell $(\mathrm{Ne})$ shows indentation of the nuclear membrane and a slight dilatation of the cisterns of the endoplasmic reticulum $(E R)$, but oligodendroglia $(O l i)$ keeps its normal structure as a whole. $\times 10,000$ Fig. 21 and 22. Oligodendroglial cell in the cerebral cortex of a 6-day-old rat, 96 hr dehydration. The outer nuclear membrane separates from the inner one forming large slender vacuoles $(\mathrm{Va})$. Note the vacuoles which may be derived from the dilated Golgi complex. $\times 16,000$ 
The present author observed that oligodendroglia had more conspicuous cytologic changes than that of astrocytes. The main cytologic changes of the dehydrated rat cerebral cortex are related to the capillary endothelium, nerve cell and oligodendroglia. The endothelial cells showed a conspicuous increase in their thickness and electron density as well as in the number of their cytoplasmic organelles as the dehydration went on. An increase in vesicles of variable size and shape was especially prominent. This increase of organelles seems to indicate an elevated cellular activity. The increase of vesicles which are supposed to move across the cytoplasm implies an enhanced permeability. Small vesicles in the endothelial cytoplasm are believed to have an important meaning as the vehicles of transport for material through the capillary wall as it was demonstrated by PALADE (1961) using marker particles injected into blood stream. The disappearance of the thin folds of the endothelial cells was observed frequently in dehydration, and in severely affected cases, junctional complex seemed to become defective. These changes may suggest an increased permeability if one takes into account an extracellular transport. PALAdE (1961) reported that the transport of colloidal particles through the wall of capillaries and larger vessels, occurred normally via pinocytosis, but that in inflammation the leakage occurred principally in the venous capillaries and venules. MAJNo and PALADE (1961) described extracellular transport more clearly. They studied the vascular permeability on inflammation using colloidal mercuric sulfide as a tracer and noted that leakage of these particles between endothelial cells did occur on occasions. The increased width of the basement membrane seems to mean increased permeability and destruction of the end-feet which are in direct contact with the basement membrane is supposed to facilitate the passage of the fluid.

In severely affected cases, endothelial cells lose their density and bulge into the lumen strikingly. These changes seem to mean a decrease in endothelial activity. Similar cytologic changes in the capillary were described in the experiment by HiLLs (1964). He studied the anoxic-ischemic lesions in the adult rat cerebral cortex and described that the histologic changes were usually characterized by a certain degree of cerebral edema and that the vascular endothelium revealed two different changes. One was the endothelial hypertrophy which was accompanied by an increase of cytoplasmic organelles and the other was the endothelial swelling. He reported that endothelial swelling only occurred in those rats which were severely affected, the swollen cells eventually obliterated the capillary lumen and pinocytotic vesicles had disappeared in the swollen endothelium. Luse (1961) studied the brain ultrastructure of the adult rabbit in dehydration and observed a peculiar vacuolation in the endothelial cytoplasm. As the main changes he pointed out vacuole formation and increased density in the endothelial cytoplasm and observed that vacuoles rapidly disappeared on rehydration of the shrunken brain. His observations on the capillary endothelium resemble the changes which the present author recognized in moderately dehydrated cases.

The present observations concerning the myelin figures are too few to reveal the significance of this structure. CEaIo (1964) divided the myelin figures into three groups, i. e., those found in normal cells, those found in degenerating or experimentally treated cells, and those which can be obtained artificially. Myelin figures of the second group were observed in many tissues, though those in the capillary 
endothelium of the cerebral cortex have not yet been described.

The most remarkable cytologic changes of nerve cells are the vacuolar dilatation of the cisterns of the endoplasmic reticulum, derangement of Nissl bodies and vacuolar swelling of mitochondria. In severe dehydration, necrotic changes such as rarefaction of the cytoplasm, vacuolar alteration and destruction of the nuclear and cytoplasmic membranes became conspicuous. Luse and HARRIs (1961) observed increased density of the cytoplasm, increased indentation in the nuclear membrane and abnormally stippled chromatin clumping in nerve cells following dehydration. GHen (1966) observed the brain in the asphyxiated newborn rabbit and stated that the most evident changes in the nerve cells were vacuolar cytoplasmic alteration, swelling of the mitochondria and vacuolar dilatation of Golgi complex. As to the other cortical elements he observed the enlargement of extracellular spaces and swelling of the neuronal and glial processes. Unfortunately, no specific changes in the nerve cell are known to be caused by dehydration; the above stated cytologic changes such as the increase of vesicles and mitochondrial alteration are common in cerebral edema, anoxia and radiation. It may be said, however, that the prompt reaction of nerve cells to dehydration suggests the significant effect of dehydration on the developing brain.

Brain ultrastructure is susceptible to influences from experimental procedures and a possible occurrence of artefact should always be taken into account. The cytological changes in the glial elements especially in the astrocytes described in the present study may not all be ascribed to the result of cerebral dehydration. To decide what are artefacts and what are experimentally induced changes in these cells, more research especially using other kinds of fixatives seem needed.

\section{Summary}

Electron microscopic observation was made on the changes in the cerebral cortex of the newborn and developing rat brain caused by dehydration. Rats ranging in age from one to four days were kept unfed for from 24 to 96 hours.

1. In the dehydrated animals, the brain capillaries became irregular in outline and the endothelial cells swelled with an increased cytoplasmic density. Vacuole formation in the endothelial cytoplasm became conspicuous and the basement membrane increased in width. Disappearance of the thin fold which overlaps endothelial cells may be recognized. The pericapillary glial processes may be destructed. These changes appear to represent a progressive reaction to the dehydration and to indicate an increased permeability in the blood brain barrier. As the dehydration goes on, these changes become more conspicuous, but in severely affected cases, swollen endothelial cells gradually lose their density with a decrease in the number of organelles.

2. The most evident and constant changes in the nerve cells are vacuolar cisternae of the rough surfaced endoplasmic reticulum, derangement of the accumulations of the reticulum cisternae as Nissl bodies and increased vesicles in the cytoplasm. Mitochondrial degeneration is not constant. These cytologic damages are recognizable in all dehydrated animals though varying considerably in degree. The vacuole formation becomes more conspicuous as the dehydration goes on.

3. Oligodendroglial cells show considerable changes such as vesiculation and 
vacuolation of the cytoplasm.

4. No remarkable changes of intracytoplasmic organelles occur in astrocyte, but shrinkage of the cell body is observed occasionally.

5. In general, cytologic changes due to dehydration are observed more frequently and strongly around the capillary.

Acknowledgement. The author wishes to express his cordial thanks to Prof. Tsuneo NAKAMURA for his kind advice during this study and helpful comments after reading the manuscript. $\mathrm{He}$ is also very grateful to Dr. Kunio Hatasa for his kind guidance.

\section{脱水の際の新生ラット大脳皮質の微細構造（内容自抄）}

新生ラットを 24 時間から 96 時間の飢餓状態におき，脱水が新生児期の中枢神経系に及 ぼす影響を電子顕微鏡を用いて形態学的に観察した。今回の実験では 脱水時の大脳皮質 の微細構造の変化を 毛細血管および神経細胞を中心に観察し，次の結果を得た.

1. 毛細血管は形が不規則となり，内皮細胞は管腔内に膨隆し，内皮細胞内には小胞の 増加，空胞の出現，粗面および滑面小胞体の拡大，ミトコンドリアの膨化などが見られ る. 基底膜は凹凹が著明となり，その幅はひろくなる．これらの変化は 透過性の克進を意 味すると考えられる．脱水が高度になると内皮細胞の電子密度は かえって低くなり，細 胞内水腫を思わせる像を呈する.

2. 神経細胞では 粗面小胞体の空胞化, 粗面小胞体の集積 (ニッスル小体) の崩壞, ミ トコンドリアの変性などがみられる. 脱水が高度になると細胞内小器官は減少し, 正常 なゴルジ体も見られなくなり，核膜は外葉と内葉が大きく離開する.

3. 神経膠細胞では，稀突起膠細胞が星状膠細胞に比べて著明な変化を示すが，てれら については内皮細胞内にみられたミエリン像とともにさらに検討を加えなければならな 々.

\section{References}

Gecio, A.: Electron microscopic observations of young rat liver. I. Distribution and structure of the myelin figures. Z. Zellforsh. $62: 717-742$ (1964).

Dempsey, E. W. and S. A. Luse : Fine structure of the neuropile in relation to neuroglia cell. In : (ed. by) W. E. Windle: Biology of neuroglia. Springfield Illinois, Charles C. Thomas, 1958. (p. 99).

Donahue, S. and G. D. Pappas : The fine structure of capillaries in the cerebral cortex of the rat at various stages of development. Amer. J. Anat. 108:331-347 (1961).

Farquhar, M. G.: Neuroglial structure and relationships as seen with the electron microscope. Anat. Rec. 121 : 291-292 (1955).

Farquhar, M. G. and J. E. Hartmann : Neuroglial structure and relationship as revealed by electron microscopy. J. Neuropathol. exp. Neurol. 16 : 18-39 (1957).

Ghen, H, I-N. Lien and T-G. Lu : Ultrastructural studies in experimental kernicterus. Amer. J. Pathol. $48: 683-711$ (1966).

Hills, C. P.: Ultrastructural changes in the capillary bed of the rat cerebral cortex in anoxicischemic brain lesion. Amer. J. Pathol. 44 :531-550 (1964).

Honjin, R.: Electron microscopy of nervous tissue. Brain and nerve (Japanese). 12:5-29 (1960). 
Kruger, L, and D. S. Maxwell : Electron microscopy of oligodendrocytes in normal rat cerebrum. Amer. J. Anat. 118:411-435 (1966).

Luse, S. A. : Electron microscopy of glial cells. Anat. Rec. 124 : 329-330 (1956).

Luse, S. A. and B. Harris : Brain ultrastructure in hydration and dehydration. Arch. Neurol. 4 : 139-152 (1961).

Majno, G. and G. E. Palade : Studies on inflammation. I. The effect of histamine and serotonin on vascular permeability. J. biophys. biochem. Cytol. 11 :571-605 (1961).

Palade, G. E .: Blood capillaries of the heart and other organes. Circulation 24 : 368-384 (1961).

Reid, W. L : Cerebral oedema. Australia an i New Zealand J. Surg. 13 : 11-36 (1943).

Schultz, R. L : Macroglial identification in electron micrographs. J. comp. Neurol. 122: 281-295 (1964).

Schultz, R. L, E. A. Maynard and D. C. Pease : Electron microscopy of neurons and neuroglia of cerebral cortex and corpus callosum. Amer. J. Anat. $100: 369-407$ (1957).

Stern, K. and K. A. C. Elliot : Experimental observation on the so-called senile changes of intracellular neurofibrils. Amer. J. Psychiat. $106:$ 190-194 (1949).

Warren, K. S. and S. Schenker : Hypoxia and ammonia toxicity. Amer. J. Physiol. 199 : 1105-1108 (1960). 